\title{
The Aging Mitochondria
}

\author{
Pierre Theurey ${ }^{1, *}$ and Paola Pizzo ${ }^{1,2, *}$ \\ 1 Department of Biomedical Sciences, University of Padova, Padova 35121, Italy \\ 2 Neuroscience Institute, National Research Council (CNR), Padova 35121, Italy \\ * Correspondence: pierre.theurey@unipd.it (P.T.); paola.pizzo@unipd.it (P.P.); Tel.: +39-049-827-6067 (P.P.)
}

Received: 26 October 2017; Accepted: 4 January 2018; Published: 9 January 2018

\begin{abstract}
Mitochondrial dysfunction is a central event in many pathologies and contributes as well to age-related processes. However, distinguishing between primary mitochondrial dysfunction driving aging and a secondary mitochondrial impairment resulting from other cell alterations remains challenging. Indeed, even though mitochondria undeniably play a crucial role in aging pathways at the cellular and organismal level, the original hypothesis in which mitochondrial dysfunction and production of free radicals represent the main driving force of cell degeneration has been strongly challenged. In this review, we will first describe mitochondrial dysfunctions observed in aged tissue, and how these features have been linked to mitochondrial reactive oxygen species (ROS)-mediated cell damage and mitochondrial DNA (mtDNA) mutations. We will also discuss the clues that led to consider mitochondria as the starting point in the aging process, and how recent research has showed that the mitochondria aging axis represents instead a more complex and multifactorial signaling pathway. New working hypothesis will be also presented in which mitochondria are considered at the center of a complex web of cell dysfunctions that eventually leads to cell senescence and death.
\end{abstract}

Keywords: aging; mitochondria; ROS; MFRTA; mitochondrial function; mtDNA mutations; mutator mouse; lifespan

\section{Introduction}

On average, a healthy person lives 80 years and one of the highest risk factors known for most human diseases and mortality is aging. Despite the utmost importance of this observation, the origin and mechanism of aging remains unclear. To this regard, substantial advances have been made through investigations performed in cells and in vivo in lower organisms, such as C. elegans and D. melanogaster, as well as in mice. The former models offer extensive experimental advantages for these studies, i.e., shorter lifespan and easier genetic manipulation.

Many evolutionary and mechanistic theories have been elaborated on, trying to explain why and how living organisms age. For instance, the "somatic mutation" theory suggests that aging is due to the increase other time in DNA damage and somatic mutation, while the "telomere loss" theory postulates a decline in cellular division capacity with age, linked to the progressive shortening of telomeres in somatic tissues. The "altered proteins and waste accumulation" theory rather advocates an accumulation over time of damaged proteins, protein turnover being essential to preserve cell function and the accumulation of altered proteins contributing to a range of age related disorders $[1,2]$. However, from a mechanistic point of view, among all the theories, those that see mitochondria as main actors occupy a particular place. Indeed, mitochondria have been at the center of one leading hypothesis for 50 years: the free radical theory [3]. Even though the scientific community has shifted to a more complex view to explain aging, embracing a network of events, mitochondria remain of high importance because of their central position in cell homeostasis of almost every tissue. Thus, as far as the description of molecular and cellular mechanisms are concerned, mitochondria have been shown to participate in every main aspect of aging: decline of stem cell functions, cellular senescence, 
"inflammaging" and many others [4,5] (Figure 1). The role of mitochondria in metabolic pathways is also particularly important. Their modulation, such as with caloric restriction and aerobic exercise, in turn, represents interventions than can increase lifespan [6,7] (Figure 1). Before any mechanistic consideration, however, the involvement of mitochondria in aging has been historically supported by several reports describing decreased mitochondrial functions in aged tissue [8].

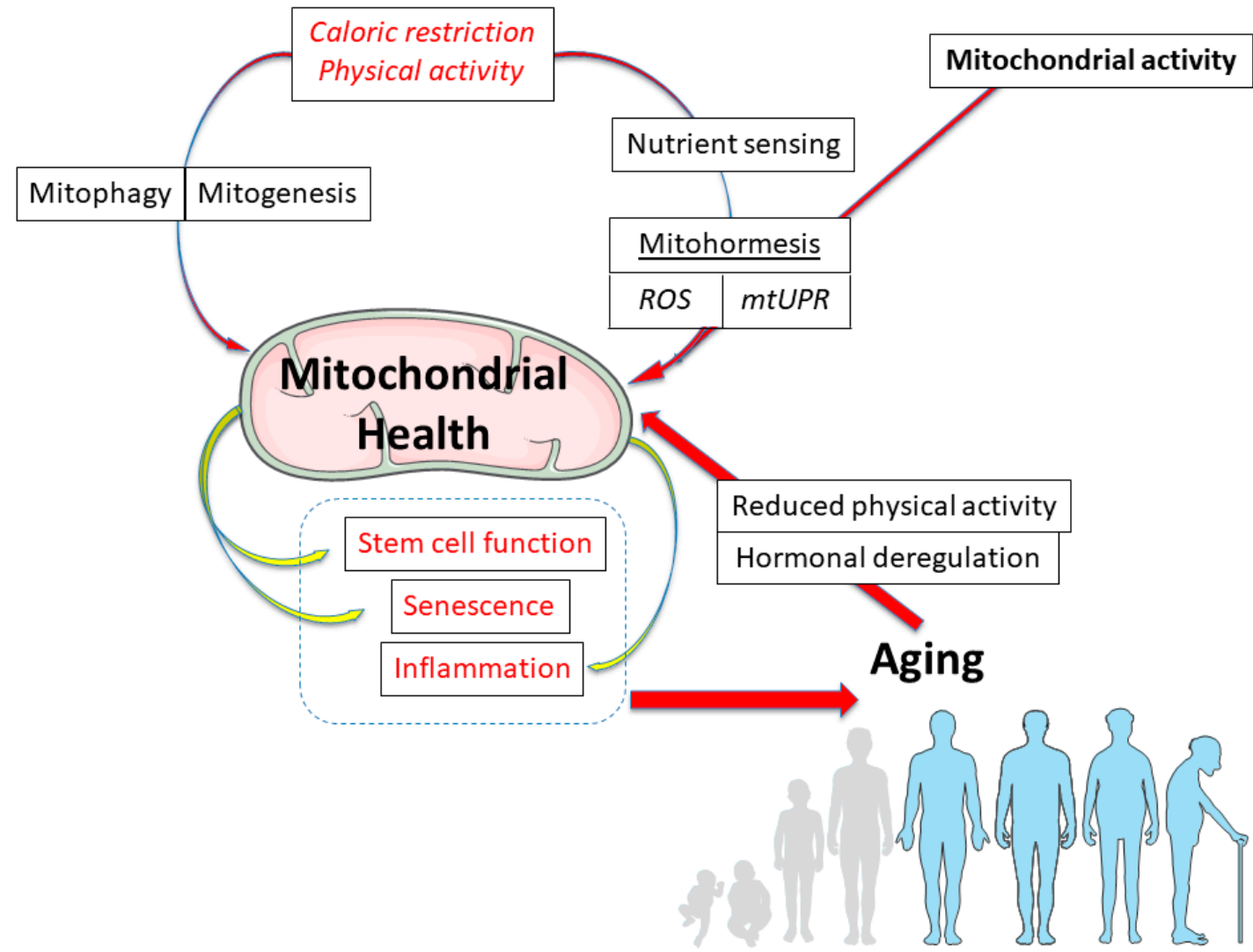

Figure 1. Mitochondrial Health at the center of a Cause-Consequence cell crossroad. The original, simplistic view of the Mitochondrial Free Radical Theory of Aging (MFRTA), postulating a mitochondrial activity/ROS/mtDNA isolated interaction, was progressively replaced by a more integrative view in which healthy mitochondria are the result of multiple cellular pathways and activities, impacting different aspects of aging, in diverse tissues and in different manners. See text for details.

\section{Mitochondrial Dysfunction Is Associated with Aging}

Mitochondrial alterations have been extensively described in aging tissues of many organs for a long time [9]. It has been particularly studied in muscle and heart [8] and sarcopenia and heart failure are two main causes of physical decline in the elderly. In particular, in these two tissues, but also in others like liver, brain and adipose tissue, mitochondrial alterations during aging are multiple. In particular, the number and density of mitochondria [10-12], as well as mitogenesis [13,14], have been showed to be reduced, whereas for mitochondrial dynamics and content contradictory inconclusive results have been reported [15,16] (see also [8] for a recent review). Importantly, mitochondrial function has been regularly reported to be impaired in different aging tissues, in terms of ATP production and respiratory chain (RC) capacity/activity [17-20].

A key reported feature of aging mitochondria was the increase in somatic point mutations and large deletions in the mitochondrial DNA (mtDNA) [21-24]. Interestingly, these mtDNA mutations have been shown to be responsible for mitochondrial dysfunction [23]. Since mtDNA is located 
very close to the major source of reactive oxygen species (ROS) [25], oxidative damages have been considered the main cause of mutations in mtDNA [26,27]. Indeed, the Mitochondrial Free Radical Theory of Aging (MFRTA) considers the oxidative damage of mtDNA as the primary event affecting RC proteins, inducing its dysfunction and increasing ROS production in a vicious cycle [3,28]. This theory was supported by a wealth of correlative data. Indeed, oxidative stress increases with age [29-31] and its reduction, by decreasing oxygen concentration or overexpressing in primary fibroblasts the extracellular or intracellular form of the copper-zinc $(\mathrm{CuZn})$ antioxidant superoxide dismutase (SOD), increases cell lifespan and reduces senescence in vitro [32-34]. Furthermore, the downregulation of the same enzyme has been shown to induce cell senescence [35]. In vivo, intracellular CuZnSOD overexpression, together with catalase, increases the lifespan in drosophila [36]. An increase of longevity was also reported in mice upon the overexpression of the mitochondrial manganese SOD [37] or a catalase targeted to mitochondria [38]. Interestingly, overexpression of the extracellular form of CuZnSOD was shown to protect mice against aging-induced cognitive impairment [39] without increasing lifespan [40]. Missing the evaluation of mitochondrial function in these studies, the origin of the discrepancies between the results from intracellular and extracellular SOD remains unclear and further investigations would be required to solve the issue. Even though mitochondrial dysfunction has been clearly established in aging tissues, the majority of the studies remained exclusively correlative and, importantly, the observed RC decline could be secondary, for example, to hormonal alterations or reduced physical activity of the aging organism [41-43].

However, the MFRTA remained arguably the main theory for aging for many decades. Yet, this theory has been strongly challenged [44-46] and the scientific community had to adjust working hypothesis to fit with a more complex mitochondria-centered network of aging mechanisms. One of the key actors of this transition came from the creation of a fast-aging animal model, the "mutator" mouse.

\section{From the Mitochondrial Free Radical Theory of Aging to a More Complex View}

The mutator mouse was created in 2004 by Nils-Göran Larsson's group, to assess the role of mtDNA mutations and oxidative stress in aging [47]. Afterward, another group developed a very similar model with the same D257A mutation [48]. The mouse carries a homozygous knock-in mutation for a proof-reading deficient catalytic subunit of the mtDNA polymerase, leading to an extensive increase in point mutations and deletions in mtDNA. Importantly, the mouse displays a reduced lifespan and premature onset of aging-related phenotypes, providing for the first time a causative link between mtDNA mutations and aged phenotypes [47]. Moreover, experimental evidence indicated that the mouse phenotypes, typical of progeria (a pathology characterized by an extremely fast aging), were driven by mtDNA alterations [48-50].

The mutator mouse, however, did not display any increased oxidative stress [48,51] even though the animal clearly exhibited substantial mitochondrial dysfunction [50,51], shedding doubts on a direct link between mtDNA mutations, ROS and mitochondrial alterations. Similarly, the N-terminal methyltransferase 1 (NRMT1) knockout mouse exhibits decreased mitochondrial function and phenotypes of premature aging, despite reduced ROS generation [52]. In addition, a study reported a lack of gain in longevity in mice overexpressing the mitochondrial manganese SOD (MnSOD), despite decreased oxidative stress and age-related decline in mitochondrial ATP production [53]. Moreover, further genetic investigations in aged individuals showed that the evolution rate of the mitochondrial mutation load was incompatible with a ROS-mediated mechanism that would predict a mutational burst not observed experimentally [7,54]. Instead, recent works suggested that de novo mutations come rather from DNA polymerase errors [55,56], or because of clonal expansion of original maternally inherited mutations [7,57,58]. The role of mtDNA mutations in the mutator mouse was furthermore challenged by different observations: (i) mtDNA mutations were order of magnitudes higher in the model animal than in aged human tissues [59]; (ii) the mutation load of corresponding control normal-aging mice were still higher than that in aged humans [60]; (iii) the heterozygous knock-in mutator mouse exhibited a major increase in mutation load, compared to that of aged wild type mice, 
with no phenotype of premature aging [61]. Additionally, concerns have arisen regarding the type of mutations accumulated in the mutator mouse, which did not include conical mtDNA deletion observed in humans [62]. Another important challenge to the mtDNA mutation-mediated theory of aging came from another mouse model. Indeed, the "deleter" mouse, which expresses a mutant-dominant version of a mitochondrial replicative helicase, exhibits accumulation of large-scale mtDNA deletions and mitochondrial dysfunctions, leading to mitochondrial myopathy without displaying premature aging phenotype [63].

All these findings found echo in studies questioning whether somatic mutations in mtDNA could ever reach a level high enough to have a significant physiological impact on mitochondrial function [63]. Indeed, among the natural mtDNA heteroplasmy, a pathogenic mutation would need to rise up from $60 \%$ to over $95 \%$ of level to have a functional impact on the RC [64-66]. This phenomenon, called mitochondrial threshold, led many scientists to doubt the real implication of mtDNA mutations in the aging process. However, an alternative hypothesis of a random mitotic segregation of mutated mtDNA, called relaxed replication of mtDNA [67], would implicate the formation of a mosaic cell distribution of mitochondrial deficiency in the aged tissue, which would actually fall in line with many experimental observations [23,56,68].

Recently, it has been demonstrated that the progeria-like phenotype of the mutator mouse derives from a somatic stem cells (SSCs) dysfunction, leading to defects in self-renewal of old post-mitotic tissues [69]. The SSCs defect is already present at the embryonic state and precedes RC malfunctioning, which arises only when the aging phenotype is already present in the mouse, strongly suggesting that the SSCs dysfunction represents an early event in the mechanisms leading to aged phenotypes.

\section{A Complex and Mitochondria-Centered View of Cell Dysfunctions in Aging}

One of the main topics of investigation in the aging field is the link between SSCs dysfunction and mitochondrial decline in aged tissue [4]. Indeed, stem cell exhaustion is a phenomenon that has been described in many tissues as part of the aging process [70-72]. One of the first indications of the role played by mitochondria in the SSCs decline was the observation that in the mutator mouse SSCs dysfunctions could be partially reversed by antioxidants [69]. Moreover, the efficiency of somatic cells reprograming into induced pluripotent stem cells (iPSC) was severely impaired in the animal, in a ROS signaling-dependent manner [73]. Interestingly, the SSCs decline is relying on point mutation accumulation in their mtDNA since the deletor mouse model, which displays mtDNA deletion only in post-mitotic tissues, does not display SSCs renewal impairment [69]. These observations fall in line with the idea that, in general, mitochondria are important in the metabolic control of stem cells pluripotency through specific mitochondrial metabolites, such as $\alpha$-ketoglurate [74] or NAD+ [75]. The importance of mitochondria in maintaining stem cells functions could also be suggested by the fact that these cells have a unique capacity to eliminate old mitochondria through increased mitophagy [76] and specific segregation of old mitochondria [77]. However, it is important to keep in mind that SSCs decline alone does not recapitulate all the features of physiological aging [78], and that mitochondria can affect many other related cellular phenomena, such as senescence.

Indeed, as for stem cells differentiation, senescence is characterized by profound metabolic changes [79] and induction or repression of senescence goes through metabolic regulation. For example, though the context might be different from aging, cell senescence mediated by oncogenes, such as $B R A F$ and $p 53$, involves the modulation of mitochondrial enzymes and metabolism [80]. Other interesting elements for understanding the complex relationship between aging and mitochondrial metabolism come from yeasts, where it has been shown that the overexpression of the mitochondrial enzyme malate dehydrogenase increases lifespan [81,82]. Moreover, from large scale screenings, many genes coding for tricarboxylic acid cycle (TCA) enzymes have been identified as potential regulators of yeast replicative lifespan [83]. These findings are supported by the ability of malate and fumarate to extend lifespan in C. elegans [84], despite the lack of experimental evidence in mouse models. Mitochondrial metabolism is also a key factor in nutrient sensing (NS) mechanisms [85] that are crucial regulators of 
lifespan. Indeed, the ability of caloric restriction (CR) to increase lifespan has been well established and this latter effect has been shown to go through mitochondrial metabolism-mediated NS. Many studies in yeast, and in a wide range of multicellular lower and higher organisms, have shown that CR simultaneously increases lifespan while improving mitochondrial activity [86-88] and mitochondrial biogenesis [89], with peroxisome proliferator-activated receptor gamma coactivator 1-alpha (PGC-l $\alpha)$ and sirtuin 1 (SIRT1) being the two main regulators of the process identified so far [90,91]. Interestingly, the inhibition of NS signaling pathways, such as the Insulin/IGF-1 [92] and mechanistic target of rapamycin (mTOR) [93,94] pathways, led to similar results. Moreover, it was further showed that ROS signaling and adenosine monophosphate (AMP)-activated protein kinase (AMPK) activation could be the common mechanism linking CR, inhibition of NS pathways and mitochondrial activity $[95,96]$.

The view of ROS as signaling molecules in the cellular antioxidant pathway, rather than deleterious byproducts, led to the concept of mitochondrial hormesis (mitohormesis), corresponding to the idea that an increase in ROS production can eventually induce an adaptive response that will overcome the increase of oxidative stress and, eventually, has beneficiary effects [97]. This is particularly true during aerobic exercise, another key intervention than can positively influence aging, which increases ROS production while simultaneously improving mitochondrial biogenesis, function, and metabolic health in the elderly [98-100]. Similarly, the link between mitochondrial function and lifespan is complex, and cannot be oversimplified to the idea that highly active mitochondria increase lifespan [89]. Indeed, studies have demonstrated that mild reduction of mitochondrial function can counter-intuitively increase lifespan in yeast, worms, flies and mice. In particular, this phenomenon was extensively studied in C. elegans, in which genetic manipulation of genes encoding RC components, to induce mild mitochondrial dysfunction, underlies some lifespan-extending programs [101-103]. This line of evidence has been further supported in different long-lived mouse models [104]. This opposite association of mitochondrial activity and lifespan was shown to involve compensatory mechanisms related to ROS signaling [105] and the mitochondrial unfolded protein response $\left(\mathrm{UPR}^{\mathrm{mt}}\right)[102,106]$. The $\mathrm{UPR}^{\mathrm{mt}}$ is an adaptive stress response to depletion in mtDNA or accumulation of unfolded proteins in the mitochondria that triggers a complete adaptive response including a nucleus-mitochondria and inter-organs cross talk for the induction of chaperone protein expression [107], ROS defense and metabolic adaptation. The UPR ${ }^{\mathrm{mt}}$ is the proof of the utmost importance of mitochondrial homeostasis for cell health since more than 400 genes are involved to activate numerous maintenance pathways in the case of mitochondrial distress, to stabilize and recover their function. A subtle equilibrium constitutes a vast mitochondrial surveillance system to monitor the health of the mitochondrial pool [108]. However, the relationship between mitochondrial dysfunction, UPR ${ }^{\mathrm{mt}}$ and longevity is complex, as it appears that UPR ${ }^{\mathrm{mt}}$ activation, alongside multiple pathways activated during mitochondrial dysfunction, is required but not sufficient for gaining longevity $[108,109]$. Another major mechanism in maintaining mitochondrial protein homeostasis is mitoproteases, proteolytic mitochondrial enzymes important in protein quality control and in preventing accumulation of misfolded proteins. Interestingly, mitoproteases overexpression increases lifespan, even though these experiments were performed only in a fungal model of aging [110,111].

When the UPR ${ }^{\mathrm{mt}}$ is overwhelmed, coordination of mitogenesis and mitophagy, which is the selective removal of damaged mitochondria by autophagy, ensures a fresh and functional pool of mitochondria sustaining cellular function [112]. Even though Parkin (a key protein in mitophagy; [113]) overexpression or suppression, respectively, increase or decrease lifespan in drosophila [114,115], direct evidence that mitophagy can modulate aging in other organisms is missing [4]. However, some clues indicate that mitophagy can modulate the effect of lifespan-controlling pathways. For example, it has been reported that the knockdown of mitophagy-related proteins decreases lifespan of mutant or CR long-lived C. elegans [116,117]. Moreover, Parkin overexpression attenuates aging-related muscle atrophy in mice [118], while its ablation decreases lifespan [119].

Thus, it appears that maintaining healthy mitochondria, not necessary active, is the central elements for healthy aging and long lifespan. The utmost importance of preserving the integrity of 
the mitochondrial pool is also sustained by the fact that mitochondria-derived damage-associated molecular patterns (DAMPs), in particular free mtDNA molecules and formylated peptides, liberated upon physical damage to mitochondria, can induce inflammatory response through multiple pathways [120-122]. Importantly, chronic inflammatory state is one of the hallmark of aging and has been termed "inflammaging" [123]. This process directly participates to the physical decline in the elderly, as illustrated by the fact that, in mice, ablation of the Nlrp3 inflammasome protects against age-related pathologies [124]. Moreover, mitochondria have been shown to mechanistically participate to the antiviral immune response: indeed, the innate immunity adaptor protein MAVS has been shown to be localized at the mitochondrial outer membrane [125]. Altogether, these findings strongly support the idea of an intimate relationship between mitochondria and the inflammatory process, in which the activation of this latter induces mitochondrial impairment and vice versa. Accordingly, many inflammatory pathologies have been associated to mitochondrial defects [126,127]. The importance of mitochondrial health in inflammation, one of the main biological response in maintaining organism homeostasis, is another example of the key role played by this organelle in the eukaryotic cell in general, beyond aging pathways.

\section{Conclusions}

Human lifespan has increased drastically in the past decades and is likely to keep raising $[127,128]$. Increasing number of people at old and very old ages will pose major challenges for healthcare systems and, in this context, the promotion of healthy aging is crucial. To this regard, the better knowledge of the molecular mechanisms behind the aging process is a main priority of modern societies. Unfortunately, they are still unclear and the current working models are of increasing complexity [129]. In the past and in the current hypotheses, mitochondria had, and still have, a key position due to their central role in eukaryotic cells/tissues, in almost every form of homeostasis (Figure 1). Even though mitochondrial impairment is clearly associated with aging, the high complexity of aging phenotypes, and their underlying molecular mechanisms, make the deciphering of the real causing elements difficult [5]. Moreover, the discovery of mitohormesis in stress response and ROS signaling pathways nuanced the idea of active and healthy mitochondria, and of ROS production and oxidative stress. Indeed, as described above, increased ROS and less active mitochondria can promote healthy aging and long lifespan. Even in this complex scenario, more than ever, acting on mitochondria seems to be an attractive perspective in order to achieve gain in health and lifespan, since rejuvenating aged mitochondria could be an interesting therapeutic strategy to improve health in the elderly (Figure 1). To this regard, the best interventions identified so far in mammals and different aging models remain dietary intervention [130-132] (i.e., caloric restriction, intermittent feeding, nutrient deprivation or other fasting-mimicking diets) and physical activity [133].

Acknowledgments: The authors thank grants from the University of Padova; the Italian Ministry of University and Scientific Research and EU Joint Programme in Neurodegenerative Disease, 2015-2018, "Cellular Bioenergetics in Neurodegenerative Diseases: A system-based pathway and target analysis" for their research work support. P.T. is a Research fellow of the EU Joint Programme in Neurodegenerative Disease grant.

Conflicts of Interest: The authors declare no conflict of interest.

\section{References}

1. Hughes, K.A.; Reynolds, R.M. Evolutionary and mechanistic theories of aging. Annu. Rev. Entomol. 2005, 50, 421-445. [CrossRef] [PubMed]

2. Kirkwood, T.B. Understanding the odd science of aging. Cell 2005, 120, 437-447. [CrossRef] [PubMed]

3. Harman, D. Aging: A theory based on free radical and radiation chemistry. J. Gerontol. 1956, 11, $298-300$. [CrossRef] [PubMed]

4. Sun, N.; Youle, R.J.; Finkel, T. The Mitochondrial Basis of Aging. Mol. Cell 2016, 61, 654-666. [CrossRef] [PubMed] 
5. Lopez-Otin, C.; Blasco, M.A.; Partridge, L.; Serrano, M.; Kroemer, G. The hallmarks of aging. Cell 2013, 153, 1194-1217. [CrossRef] [PubMed]

6. Bratic, A.; Larsson, N.G. The role of mitochondria in aging. J. Clin. Investig. 2013, 123, 951-957. [CrossRef] [PubMed]

7. Payne, B.A.; Chinnery, P.F. Mitochondrial dysfunction in aging: Much progress but many unresolved questions. Biochim. Biophys. Acta 2015, 1847, 1347-1353. [CrossRef] [PubMed]

8. Boengler, K.; Kosiol, M.; Mayr, M.; Schulz, R.; Rohrbach, S. Mitochondria and ageing: Role in heart, skeletal muscle and adipose tissue. J. Cachexia Sarcopenia Muscle 2017, 8, 349-369. [CrossRef] [PubMed]

9. Shigenaga, M.K.; Hagen, T.M.; Ames, B.N. Oxidative damage and mitochondrial decay in aging. Proc. Natl. Acad. Sci. USA 1994, 91, 10771-10778. [CrossRef] [PubMed]

10. Corsetti, G.; Pasini, E.; Dantona, G.; Nisoli, E.; Flati, V.; Assanelli, D.; Dioguardi, F.S.; Bianchi, R. Morphometric changes induced by amino acid supplementation in skeletal and cardiac muscles of old mice. Am. J. Cardiol. 2008, 101, 26E-34E. [CrossRef] [PubMed]

11. Tauchi, H.; Sato, T. Age changes in size and number of mitochondria of human hepatic cells. J. Gerontol. 1968, 23, 454-461. [CrossRef] [PubMed]

12. Herbener, G.H. A morphometric study of age-dependent changes in mitochondrial population of mouse liver and heart. J. Gerontol. 1976, 31, 8-12. [CrossRef] [PubMed]

13. Moreno-Ulloa, A.; Nogueira, L.; Rodriguez, A.; Barboza, J.; Hogan, M.C.; Ceballos, G.; Villarreal, F.; Ramirez-Sanchez, I. Recovery of Indicators of Mitochondrial Biogenesis, Oxidative Stress, and Aging With (-)-Epicatechin in Senile Mice. J. Gerontol. A 2015, 70, 1370-1378. [CrossRef] [PubMed]

14. Reznick, R.M.; Zong, H.; Li, J.; Morino, K.; Moore, I.K.; Yu, H.J.; Liu, Z.X.; Dong, J.; Mustard, K.J.; Hawley, S.A.; et al. Aging-associated reductions in AMP-activated protein kinase activity and mitochondrial biogenesis. Cell Metab. 2007, 5, 151-156. [CrossRef] [PubMed]

15. Iqbal, S.; Ostojic, O.; Singh, K.; Joseph, A.M.; Hood, D.A. Expression of mitochondrial fission and fusion regulatory proteins in skeletal muscle during chronic use and disuse. Muscle Nerve 2013, 48, 963-970. [CrossRef] [PubMed]

16. Joseph, A.M.; Adhihetty, P.J.; Wawrzyniak, N.R.; Wohlgemuth, S.E.; Picca, A.; Kujoth, G.C.; Prolla, T.A.; Leeuwenburgh, C. Dysregulation of mitochondrial quality control processes contribute to sarcopenia in a mouse model of premature aging. PLoS ONE 2013, 8, e69327. [CrossRef] [PubMed]

17. Preston, C.C.; Oberlin, A.S.; Holmuhamedov, E.L.; Gupta, A.; Sagar, S.; Syed, R.H.; Siddiqui, S.A.; Raghavakaimal, S.; Terzic, A.; Jahangir, A. Aging-induced alterations in gene transcripts and functional activity of mitochondrial oxidative phosphorylation complexes in the heart. Mech. Ageing Dev. 2008, 129, 304-312. [CrossRef] [PubMed]

18. Short, K.R.; Bigelow, M.L.; Kahl, J.; Singh, R.; Coenen-Schimke, J.; Raghavakaimal, S.; Nair, K.S. Decline in skeletal muscle mitochondrial function with aging in humans. Proc. Natl. Acad. Sci. USA 2005, 102, 5618-5623. [CrossRef] [PubMed]

19. Ojaimi, J.; Masters, C.L.; Opeskin, K.; McKelvie, P.; Byrne, E. Mitochondrial respiratory chain activity in the human brain as a function of age. Mech. Ageing Dev. 1999, 111, 39-47. [CrossRef]

20. Sastre, J.; Pallardo, F.V.; Pla, R.; Pellin, A.; Juan, G.; O'Connor, J.E.; Estrela, J.M.; Miquel, J.; Vina, J. Aging of the liver: Age-associated mitochondrial damage in intact hepatocytes. Hepatology 1996, 24, 1199-1205. [CrossRef] [PubMed]

21. Corral-Debrinski, M.; Horton, T.; Lott, M.T.; Shoffner, J.M.; Beal, M.F.; Wallace, D.C. Mitochondrial DNA deletions in human brain: Regional variability and increase with advanced age. Nat. Genet. 1992, 2, 324-329. [CrossRef] [PubMed]

22. Yen, T.C.; Su, J.H.; King, K.L.; Wei, Y.H. Ageing-associated 5 kb deletion in human liver mitochondrial DNA. Biochem. Biophys. Res. Commun. 1991, 178, 124-131. [CrossRef]

23. Fayet, G.; Jansson, M.; Sternberg, D.; Moslemi, A.R.; Blondy, P.; Lombes, A.; Fardeau, M.; Oldfors, A. Ageing muscle: Clonal expansions of mitochondrial DNA point mutations and deletions cause focal impairment of mitochondrial function. Neuromuscul. Disord. 2002, 12, 484-493. [CrossRef]

24. Cortopassi, G.A.; Arnheim, N. Detection of a specific mitochondrial DNA deletion in tissues of older humans. Nucleic Acids Res. 1990, 18, 6927-6933. [CrossRef] [PubMed] 
25. Alexeyev, M.; Shokolenko, I.; Wilson, G.; LeDoux, S. The maintenance of mitochondrial DNA integrity—critical analysis and update. Cold Spring Harb. Perspect. Biol. 2013, 5, a012641. [CrossRef] [PubMed]

26. Richter, C. Oxidative damage to mitochondrial DNA and its relationship to ageing. Int. J. Biochem. Cell Biol. 1995, 27, 647-653. [CrossRef]

27. Mecocci, P.; Fano, G.; Fulle, S.; MacGarvey, U.; Shinobu, L.; Polidori, M.C.; Cherubini, A.; Vecchiet, J.; Senin, U.; Beal, M.F. Age-dependent increases in oxidative damage to DNA, lipids, and proteins in human skeletal muscle. Free Radic. Biol. Med. 1999, 26, 303-308. [CrossRef]

28. Fraga, C.G.; Shigenaga, M.K.; Park, J.W.; Degan, P.; Ames, B.N. Oxidative damage to DNA during aging: 8-hydroxy-2'-deoxyguanosine in rat organ DNA and urine. Proc. Natl. Acad. Sci. USA 1990, 87, 4533-4537. [CrossRef] [PubMed]

29. Suh, J.H.; Heath, S.H.; Hagen, T.M. Two subpopulations of mitochondria in the aging rat heart display heterogenous levels of oxidative stress. Free Radic. Biol. Med. 2003, 35, 1064-1072. [CrossRef]

30. Choksi, K.B.; Nuss, J.E.; Deford, J.H.; Papaconstantinou, J. Age-related alterations in oxidatively damaged proteins of mouse skeletal muscle mitochondrial electron transport chain complexes. Free Radic. Biol. Med. 2008, 45, 826-838. [CrossRef] [PubMed]

31. Beal, M.F. Oxidatively modified proteins in aging and disease. Free Radic. Biol. Med. 2002, 32, 797-803. [CrossRef]

32. Packer, L.; Fuehr, K. Low oxygen concentration extends the lifespan of cultured human diploid cells. Nature 1977, 267, 423-425. [CrossRef] [PubMed]

33. Serra, V.; von Zglinicki, T.; Lorenz, M.; Saretzki, G. Extracellular superoxide dismutase is a major antioxidant in human fibroblasts and slows telomere shortening. J. Biol. Chem. 2003, 278, 6824-6830. [CrossRef] [PubMed]

34. Lee, A.C.; Fenster, B.E.; Ito, H.; Takeda, K.; Bae, N.S.; Hirai, T.; Yu, Z.X.; Ferrans, V.J.; Howard, B.H.; Finkel, T. Ras proteins induce senescence by altering the intracellular levels of reactive oxygen species. J. Biol. Chem. 1999, 274, 7936-7940. [CrossRef] [PubMed]

35. Blander, G.; de Oliveira, R.M.; Conboy, C.M.; Haigis, M.; Guarente, L. Superoxide dismutase 1 knock-down induces senescence in human fibroblasts. J. Biol. Chem. 2003, 278, 38966-38969. [CrossRef] [PubMed]

36. Orr, W.C.; Sohal, R.S. Extension of life-span by overexpression of superoxide dismutase and catalase in Drosophila melanogaster. Science 1994, 263, 1128-1130. [CrossRef] [PubMed]

37. Hu, D.; Cao, P.; Thiels, E.; Chu, C.T.; Wu, G.Y.; Oury, T.D.; Klann, E. Hippocampal long-term potentiation, memory, and longevity in mice that overexpress mitochondrial superoxide dismutase. Neurobiol. Learn. Mem. 2007, 87, 372-384. [CrossRef] [PubMed]

38. Schriner, S.E.; Linford, N.J.; Martin, G.M.; Treuting, P.; Ogburn, C.E.; Emond, M.; Coskun, P.E.; Ladiges, W.; Wolf, N.; Van Remmen, H.; et al. Extension of murine life span by overexpression of catalase targeted to mitochondria. Science 2005, 308, 1909-1911. [CrossRef] [PubMed]

39. Levin, E.D.; Christopher, N.C.; Lateef, S.; Elamir, B.M.; Patel, M.; Liang, L.P.; Crapo, J.D. Extracellular superoxide dismutase overexpression protects against aging-induced cognitive impairment in mice. Behav. Genet. 2002, 32, 119-125. [CrossRef] [PubMed]

40. Levin, E.D.; Christopher, N.C.; Crapo, J.D. Memory decline of aging reduced by extracellular superoxide dismutase overexpression. Behav. Genet. 2005, 35, 447-453. [CrossRef] [PubMed]

41. Larsen, R.G.; Callahan, D.M.; Foulis, S.A.; Kent-Braun, J.A. Age-related changes in oxidative capacity differ between locomotory muscles and are associated with physical activity behavior. Appl. Physiol. Nutr. Metab. 2012, 37, 88-99. [CrossRef] [PubMed]

42. Begin, M.E.; Langlois, M.F.; Lorrain, D.; Cunnane, S.C. Thyroid Function and Cognition during Aging. Curr. Gerontol. Geriatr. Res. 2008, 2008, 474868. [CrossRef] [PubMed]

43. Weitzel, J.M.; Iwen, K.A.; Seitz, H.J. Regulation of mitochondrial biogenesis by thyroid hormone. Exp. Physiol. 2003, 88, 121-128. [CrossRef] [PubMed]

44. Stuart, J.A.; Maddalena, L.A.; Merilovich, M.; Robb, E.L. A midlife crisis for the mitochondrial free radical theory of aging. Longev. Healthspan 2014, 3, 4. [CrossRef] [PubMed]

45. Lapointe, J.; Hekimi, S. When a theory of aging ages badly. Cell. Mol. Life Sci. 2010, 67, 1-8. [CrossRef] [PubMed] 
46. Barja, G. Updating the mitochondrial free radical theory of aging: An integrated view, key aspects, and confounding concepts. Antioxid. Redox Signal. 2013, 19, 1420-1445. [CrossRef] [PubMed]

47. Trifunovic, A.; Wredenberg, A.; Falkenberg, M.; Spelbrink, J.N.; Rovio, A.T.; Bruder, C.E.; Bohlooly, Y.M.; Gidlof, S.; Oldfors, A.; Wibom, R.; et al. Premature ageing in mice expressing defective mitochondrial DNA polymerase. Nature 2004, 429, 417-423. [CrossRef] [PubMed]

48. Kujoth, G.C.; Hiona, A.; Pugh, T.D.; Someya, S.; Panzer, K.; Wohlgemuth, S.E.; Hofer, T.; Seo, A.Y.; Sullivan, R.; Jobling, W.A.; et al. Mitochondrial DNA mutations, oxidative stress, and apoptosis in mammalian aging. Science 2005, 309, 481-484. [CrossRef] [PubMed]

49. Vermulst, M.; Wanagat, J.; Kujoth, G.C.; Bielas, J.H.; Rabinovitch, P.S.; Prolla, T.A.; Loeb, L.A. DNA deletions and clonal mutations drive premature aging in mitochondrial mutator mice. Nat. Genet. 2008, 40, 392-394. [CrossRef] [PubMed]

50. Edgar, D.; Shabalina, I.; Camara, Y.; Wredenberg, A.; Calvaruso, M.A.; Nijtmans, L.; Nedergaard, J.; Cannon, B.; Larsson, N.G.; Trifunovic, A. Random point mutations with major effects on protein-coding genes are the driving force behind premature aging in mtDNA mutator mice. Cell Metab. 2009, 10, 131-138. [CrossRef] [PubMed]

51. Trifunovic, A.; Hansson, A.; Wredenberg, A.; Rovio, A.T.; Dufour, E.; Khvorostov, I.; Spelbrink, J.N.; Wibom, R.; Jacobs, H.T.; Larsson, N.G. Somatic mtDNA mutations cause aging phenotypes without affecting reactive oxygen species production. Proc. Natl. Acad. Sci. USA 2005, 102, 17993-17998. [CrossRef] [PubMed]

52. Bonsignore, L.A.; Tooley, J.G.; Van Hoose, P.M.; Wang, E.; Cheng, A.; Cole, M.P.; Schaner Tooley, C.E. NRMT1 knockout mice exhibit phenotypes associated with impaired DNA repair and premature aging. Mech. Ageing Dev. 2015, 146-148, 42-52. [CrossRef] [PubMed]

53. Jang, Y.C.; Perez, V.I.; Song, W.; Lustgarten, M.S.; Salmon, A.B.; Mele, J.; Qi, W.; Liu, Y.; Liang, H.; Chaudhuri, A.; et al. Overexpression of Mn superoxide dismutase does not increase life span in mice. J. Gerontol. A 2009, 64, 1114-1125. [CrossRef] [PubMed]

54. Greaves, L.C.; Beadle, N.E.; Taylor, G.A.; Commane, D.; Mathers, J.C.; Khrapko, K.; Turnbull, D.M. Quantification of mitochondrial DNA mutation load. Aging Cell 2009, 8, 566-572. [CrossRef] [PubMed]

55. Samuels, D.C.; Schon, E.A.; Chinnery, P.F. Two direct repeats cause most human mtDNA deletions. Trends Genet. 2004, 20, 393-398. [CrossRef] [PubMed]

56. Larsson, N.G. Somatic mitochondrial DNA mutations in mammalian aging. Annu. Rev. Biochem. 2010, 79, 683-706. [CrossRef] [PubMed]

57. Payne, B.A.; Wilson, I.J.; Yu-Wai-Man, P.; Coxhead, J.; Deehan, D.; Horvath, R.; Taylor, R.W.; Samuels, D.C.; Santibanez-Koref, M.; Chinnery, P.F. Universal heteroplasmy of human mitochondrial DNA. Hum. Mol. Genet. 2013, 22, 384-390. [CrossRef] [PubMed]

58. Ross, J.M.; Stewart, J.B.; Hagstrom, E.; Brene, S.; Mourier, A.; Coppotelli, G.; Freyer, C.; Lagouge, M.; Hoffer, B.J.; Olson, L.; et al. Germline mitochondrial DNA mutations aggravate ageing and can impair brain development. Nature 2013, 501, 412-415. [CrossRef] [PubMed]

59. Khrapko, K.; Vijg, J. Mitochondrial DNA mutations and aging: A case closed? Nat. Genet. 2007, 39, 445-446. [CrossRef] [PubMed]

60. Khrapko, K.; Kraytsberg, Y.; de Grey, A.D.; Vijg, J.; Schon, E.A. Does premature aging of the mtDNA mutator mouse prove that mtDNA mutations are involved in natural aging? Aging Cell 2006, 5, 279-282. [CrossRef] [PubMed]

61. Vermulst, M.; Bielas, J.H.; Kujoth, G.C.; Ladiges, W.C.; Rabinovitch, P.S.; Prolla, T.A.; Loeb, L.A. Mitochondrial point mutations do not limit the natural lifespan of mice. Nat. Genet. 2007, 39, 540-543. [CrossRef] [PubMed]

62. Williams, S.L.; Huang, J.; Edwards, Y.J.; Ulloa, R.H.; Dillon, L.M.; Prolla, T.A.; Vance, J.M.; Moraes, C.T.; Zuchner, S. The mtDNA mutation spectrum of the progeroid Polg mutator mouse includes abundant control region multimers. Cell Metab. 2010, 12, 675-682. [CrossRef] [PubMed]

63. Tyynismaa, H.; Mjosund, K.P.; Wanrooij, S.; Lappalainen, I.; Ylikallio, E.; Jalanko, A.; Spelbrink, J.N.; Paetau, A.; Suomalainen, A. Mutant mitochondrial helicase Twinkle causes multiple mtDNA deletions and a late-onset mitochondrial disease in mice. Proc. Natl. Acad. Sci. USA 2005, 102, 17687-17692. [CrossRef] [PubMed]

64. Hayashi, J.; Ohta, S.; Kikuchi, A.; Takemitsu, M.; Goto, Y.; Nonaka, I. Introduction of disease-related mitochondrial DNA deletions into HeLa cells lacking mitochondrial DNA results in mitochondrial dysfunction. Proc. Natl. Acad. Sci. USA 1991, 88, 10614-10618. [CrossRef] [PubMed] 
65. Holme, E.; Larsson, N.G.; Oldfors, A.; Tulinius, M.; Sahlin, P.; Stenman, G. Multiple symmetric lipomas with high levels of mtDNA with the tRNA(Lys) $A \longrightarrow G(8344)$ mutation as the only manifestation of disease in a carrier of myoclonus epilepsy and ragged-red fibers (MERRF) syndrome. Am. J. Hum. Genet. 1993, 52, 551-556. [PubMed]

66. Chomyn, A.; Martinuzzi, A.; Yoneda, M.; Daga, A.; Hurko, O.; Johns, D.; Lai, S.T.; Nonaka, I.; Angelini, C.; Attardi, G. MELAS mutation in mtDNA binding site for transcription termination factor causes defects in protein synthesis and in respiration but no change in levels of upstream and downstream mature transcripts. Proc. Natl. Acad. Sci. USA 1992, 89, 4221-4225. [CrossRef] [PubMed]

67. Chinnery, P.F.; Samuels, D.C. Relaxed replication of mtDNA: A model with implications for the expression of disease. Am. J. Hum. Genet. 1999, 64, 1158-1165. [CrossRef] [PubMed]

68. Durham, S.E.; Bonilla, E.; Samuels, D.C.; DiMauro, S.; Chinnery, P.F. Mitochondrial DNA copy number threshold in mtDNA depletion myopathy. Neurology 2005, 65, 453-455. [CrossRef] [PubMed]

69. Ahlqvist, K.J.; Hamalainen, R.H.; Yatsuga, S.; Uutela, M.; Terzioglu, M.; Gotz, A.; Forsstrom, S.; Salven, P.; Angers-Loustau, A.; Kopra, O.H.; et al. Somatic progenitor cell vulnerability to mitochondrial DNA mutagenesis underlies progeroid phenotypes in Polg mutator mice. Cell Metab. 2012, 15, 100-109. [CrossRef] [PubMed]

70. Rossi, D.J.; Bryder, D.; Seita, J.; Nussenzweig, A.; Hoeijmakers, J.; Weissman, I.L. Deficiencies in DNA damage repair limit the function of haematopoietic stem cells with age. Nature 2007, 447, 725-729. [CrossRef] [PubMed]

71. Conboy, I.M.; Rando, T.A. Heterochronic parabiosis for the study of the effects of aging on stem cells and their niches. Cell Cycle 2012, 11, 2260-2267. [CrossRef] [PubMed]

72. Carlson, M.E.; Conboy, M.J.; Hsu, M.; Barchas, L.; Jeong, J.; Agrawal, A.; Mikels, A.J.; Agrawal, S.; Schaffer, D.V.; Conboy, I.M. Relative roles of TGF-beta1 and Wnt in the systemic regulation and aging of satellite cell responses. Aging Cell 2009, 8, 676-689. [CrossRef] [PubMed]

73. Hamalainen, R.H.; Ahlqvist, K.J.; Ellonen, P.; Lepisto, M.; Logan, A.; Otonkoski, T.; Murphy, M.P.; Suomalainen, A. mtDNA Mutagenesis Disrupts Pluripotent Stem Cell Function by Altering Redox Signaling. Cell Rep. 2015, 11, 1614-1624. [CrossRef] [PubMed]

74. Carey, B.W.; Finley, L.W.; Cross, J.R.; Allis, C.D.; Thompson, C.B. Intracellular alpha-ketoglutarate maintains the pluripotency of embryonic stem cells. Nature 2015, 518, 413-416. [CrossRef] [PubMed]

75. Stein, L.R.; Imai, S. Specific ablation of Nampt in adult neural stem cells recapitulates their functional defects during aging. EMBO J. 2014, 33, 1321-1340. [CrossRef] [PubMed]

76. Sun, N.; Yun, J.; Liu, J.; Malide, D.; Liu, C.; Rovira, I.I.; Holmstrom, K.M.; Fergusson, M.M.; Yoo, Y.H.; Combs, C.A.; et al. Measuring In Vivo Mitophagy. Mol. Cell 2015, 60, 685-696. [CrossRef] [PubMed]

77. Katajisto, P.; Dohla, J.; Chaffer, C.L.; Pentinmikko, N.; Marjanovic, N.; Iqbal, S.; Zoncu, R.; Chen, W.; Weinberg, R.A.; Sabatini, D.M. Stem cells. Asymmetric apportioning of aged mitochondria between daughter cells is required for stemness. Science 2015, 348, 340-343. [CrossRef] [PubMed]

78. Norddahl, G.L.; Pronk, C.J.; Wahlestedt, M.; Sten, G.; Nygren, J.M.; Ugale, A.; Sigvardsson, M.; Bryder, D. Accumulating mitochondrial DNA mutations drive premature hematopoietic aging phenotypes distinct from physiological stem cell aging. Cell Stem Cell 2011, 8, 499-510. [CrossRef] [PubMed]

79. Quijano, C.; Cao, L.; Fergusson, M.M.; Romero, H.; Liu, J.; Gutkind, S.; Rovira, I.I.; Mohney, R.P.; Karoly, E.D.; Finkel, T. Oncogene-induced senescence results in marked metabolic and bioenergetic alterations. Cell Cycle 2012, 11, 1383-1392. [CrossRef] [PubMed]

80. Jiang, P.; Du, W.; Mancuso, A.; Wellen, K.E.; Yang, X. Reciprocal regulation of p53 and malic enzymes modulates metabolism and senescence. Nature 2013, 493, 689-693. [CrossRef] [PubMed]

81. Easlon, E.; Tsang, F.; Skinner, C.; Wang, C.; Lin, S.J. The malate-aspartate NADH shuttle components are novel metabolic longevity regulators required for calorie restriction-mediated life span extension in yeast. Genes Dev. 2008, 22, 931-944. [CrossRef] [PubMed]

82. Kaplon, J.; Zheng, L.; Meissl, K.; Chaneton, B.; Selivanov, V.A.; Mackay, G.; van der Burg, S.H.; Verdegaal, E.M.; Cascante, M.; Shlomi, T.; et al. A key role for mitochondrial gatekeeper pyruvate dehydrogenase in oncogene-induced senescence. Nature 2013, 498, 109-112. [CrossRef] [PubMed] 
83. McCormick, M.A.; Delaney, J.R.; Tsuchiya, M.; Tsuchiyama, S.; Shemorry, A.; Sim, S.; Chou, A.C.; Ahmed, U.; Carr, D.; Murakami, C.J.; et al. A Comprehensive Analysis of Replicative Lifespan in 4,698 Single-Gene Deletion Strains Uncovers Conserved Mechanisms of Aging. Cell Metab. 2015, 22, 895-906. [CrossRef] [PubMed]

84. Edwards, C.B.; Copes, N.; Brito, A.G.; Canfield, J.; Bradshaw, P.C. Malate and fumarate extend lifespan in Caenorhabditis elegans. PLoS ONE 2013, 8, e58345. [CrossRef] [PubMed]

85. Theurey, P.; Rieusset, J. Mitochondria-Associated Membranes Response to Nutrient Availability and Role in Metabolic Diseases. Trends Endocrinol. Metab. 2017, 28, 32-45. [CrossRef] [PubMed]

86. Choi, J.S.; Choi, K.M.; Lee, C.K. Caloric restriction improves efficiency and capacity of the mitochondrial electron transport chain in Saccharomyces cerevisiae. Biochem. Biophys. Res. Commun. 2011, 409, 308-314. [CrossRef] [PubMed]

87. Schulz, T.J.; Zarse, K.; Voigt, A.; Urban, N.; Birringer, M.; Ristow, M. Glucose restriction extends Caenorhabditis elegans life span by inducing mitochondrial respiration and increasing oxidative stress. Cell Metab. 2007, 6, 280-293. [CrossRef] [PubMed]

88. Colman, R.J.; Anderson, R.M.; Johnson, S.C.; Kastman, E.K.; Kosmatka, K.J.; Beasley, T.M.; Allison, D.B.; Cruzen, C.; Simmons, H.A.; Kemnitz, J.W.; et al. Caloric restriction delays disease onset and mortality in rhesus monkeys. Science 2009, 325, 201-204. [CrossRef] [PubMed]

89. Lopez-Lluch, G.; Hunt, N.; Jones, B.; Zhu, M.; Jamieson, H.; Hilmer, S.; Cascajo, M.V.; Allard, J.; Ingram, D.K.; Navas, P.; et al. Calorie restriction induces mitochondrial biogenesis and bioenergetic efficiency. Proc. Natl. Acad. Sci. USA 2006, 103, 1768-1773. [CrossRef] [PubMed]

90. Anderson, R.M.; Barger, J.L.; Edwards, M.G.; Braun, K.H.; O'Connor, C.E.; Prolla, T.A.; Weindruch, R. Dynamic regulation of PGC-1alpha localization and turnover implicates mitochondrial adaptation in calorie restriction and the stress response. Aging Cell 2008, 7, 101-111. [CrossRef] [PubMed]

91. Haigis, M.C.; Guarente, L.P. Mammalian sirtuins-emerging roles in physiology, aging, and calorie restriction. Genes Dev. 2006, 20, 2913-2921. [CrossRef] [PubMed]

92. Holzenberger, M.; Dupont, J.; Ducos, B.; Leneuve, P.; Geloen, A.; Even, P.C.; Cervera, P.; Le Bouc, Y. IGF-1 receptor regulates lifespan and resistance to oxidative stress in mice. Nature 2003, 421, 182-187. [CrossRef] [PubMed]

93. Bonawitz, N.D.; Chatenay-Lapointe, M.; Pan, Y.; Shadel, G.S. Reduced TOR signaling extends chronological life span via increased respiration and upregulation of mitochondrial gene expression. Cell Metab. 2007, 5, 265-277. [CrossRef] [PubMed]

94. Kapahi, P.; Zid, B.M.; Harper, T.; Koslover, D.; Sapin, V.; Benzer, S. Regulation of lifespan in Drosophila by modulation of genes in the TOR signaling pathway. Curr. Biol. 2004, 14, 885-890. [CrossRef] [PubMed]

95. Selman, C.; Tullet, J.M.; Wieser, D.; Irvine, E.; Lingard, S.J.; Choudhury, A.I.; Claret, M.; Al-Qassab, H.; Carmignac, D.; Ramadani, F.; et al. Ribosomal protein S6 kinase 1 signaling regulates mammalian life span. Science 2009, 326, 140-144. [CrossRef] [PubMed]

96. Zarse, K.; Schmeisser, S.; Groth, M.; Priebe, S.; Beuster, G.; Kuhlow, D.; Guthke, R.; Platzer, M.; Kahn, C.R.; Ristow, M. Impaired insulin/IGF1 signaling extends life span by promoting mitochondrial L-proline catabolism to induce a transient ROS signal. Cell Metab. 2012, 15, 451-465. [CrossRef] [PubMed]

97. Ristow, M.; Zarse, K. How increased oxidative stress promotes longevity and metabolic health: The concept of mitochondrial hormesis (mitohormesis). Exp. Gerontol. 2010, 45, 410-418. [CrossRef] [PubMed]

98. Ristow, M.; Zarse, K.; Oberbach, A.; Kloting, N.; Birringer, M.; Kiehntopf, M.; Stumvoll, M.; Kahn, C.R.; Bluher, M. Antioxidants prevent health-promoting effects of physical exercise in humans. Proc. Natl. Acad. Sci. USA 2009, 106, 8665-8670. [CrossRef] [PubMed]

99. Safdar, A.; Hamadeh, M.J.; Kaczor, J.J.; Raha, S.; Debeer, J.; Tarnopolsky, M.A. Aberrant mitochondrial homeostasis in the skeletal muscle of sedentary older adults. PLoS ONE 2010, 5, e10778. [CrossRef] [PubMed]

100. Menshikova, E.V.; Ritov, V.B.; Fairfull, L.; Ferrell, R.E.; Kelley, D.E.; Goodpaster, B.H. Effects of exercise on mitochondrial content and function in aging human skeletal muscle. J. Gerontol. A 2006, 61, 534-540. [CrossRef]

101. Lee, S.J.; Hwang, A.B.; Kenyon, C. Inhibition of respiration extends C. elegans life span via reactive oxygen species that increase HIF-1 activity. Curr. Biol. 2010, 20, 2131-2136. [CrossRef] [PubMed] 
102. Durieux, J.; Wolff, S.; Dillin, A. The cell-non-autonomous nature of electron transport chain-mediated longevity. Cell 2011, 144, 79-91. [CrossRef] [PubMed]

103. Yang, W.; Hekimi, S. A mitochondrial superoxide signal triggers increased longevity in Caenorhabditis elegans. PLoS Biol. 2010, 8, e1000556. [CrossRef] [PubMed]

104. Liu, X.; Jiang, N.; Hughes, B.; Bigras, E.; Shoubridge, E.; Hekimi, S. Evolutionary conservation of the clk-1-dependent mechanism of longevity: Loss of mclk1 increases cellular fitness and lifespan in mice. Genes Dev. 2005, 19, 2424-2434. [CrossRef] [PubMed]

105. Owusu-Ansah, E.; Song, W.; Perrimon, N. Muscle mitohormesis promotes longevity via systemic repression of insulin signaling. Cell 2013, 155, 699-712. [CrossRef] [PubMed]

106. Yee, C.; Yang, W.; Hekimi, S. The intrinsic apoptosis pathway mediates the pro-longevity response to mitochondrial ROS in C. elegans. Cell 2014, 157, 897-909. [CrossRef] [PubMed]

107. Zhao, Q.; Wang, J.; Levichkin, I.V.; Stasinopoulos, S.; Ryan, M.T.; Hoogenraad, N.J. A mitochondrial specific stress response in mammalian cells. EMBO J. 2002, 21, 4411-4419. [CrossRef] [PubMed]

108. Schulz, A.M.; Haynes, C.M. UPR(mt)-mediated cytoprotection and organismal aging. Biochim. Biophys. Acta 2015, 1847, 1448-1456. [CrossRef] [PubMed]

109. Rauthan, M.; Ranji, P.; Aguilera Pradenas, N.; Pitot, C.; Pilon, M. The mitochondrial unfolded protein response activator ATFS-1 protects cells from inhibition of the mevalonate pathway. Proc. Natl. Acad. Sci. USA 2013, 110, 5981-5986. [CrossRef] [PubMed]

110. Luce, K.; Osiewacz, H.D. Increasing organismal healthspan by enhancing mitochondrial protein quality control. Nat. Cell Biol. 2009, 11, 852-858. [CrossRef] [PubMed]

111. Quiros, P.M.; Langer, T.; Lopez-Otin, C. New roles for mitochondrial proteases in health, ageing and disease. Nat. Rev. Mol. Cell Biol. 2015, 16, 345-359. [CrossRef] [PubMed]

112. Palikaras, K.; Lionaki, E.; Tavernarakis, N. Coupling mitogenesis and mitophagy for longevity. Autophagy 2015, 11, 1428-1430. [CrossRef] [PubMed]

113. Jin, S.M.; Youle, R.J. PINK1- and Parkin-mediated mitophagy at a glance. J. Cell Sci. 2012, 125, 795-799. [CrossRef] [PubMed]

114. Greene, J.C.; Whitworth, A.J.; Kuo, I.; Andrews, L.A.; Feany, M.B.; Pallanck, L.J. Mitochondrial pathology and apoptotic muscle degeneration in Drosophila parkin mutants. Proc. Natl. Acad. Sci. USA 2003, 100, 4078-4083. [CrossRef] [PubMed]

115. Rana, A.; Rera, M.; Walker, D.W. Parkin overexpression during aging reduces proteotoxicity, alters mitochondrial dynamics, and extends lifespan. Proc. Natl. Acad. Sci. USA 2013, 110, 8638-8643. [CrossRef] [PubMed]

116. Palikaras, K.; Lionaki, E.; Tavernarakis, N. Coordination of mitophagy and mitochondrial biogenesis during ageing in C. elegans. Nature 2015, 521, 525-528. [CrossRef] [PubMed]

117. Melendez, A.; Talloczy, Z.; Seaman, M.; Eskelinen, E.L.; Hall, D.H.; Levine, B. Autophagy genes are essential for dauer development and life-span extension in C. elegans. Science 2003, 301, 1387-1391. [CrossRef] [PubMed]

118. Reynaud, O.; Leduc-Gaudet, J.P.; Hussain, S.; Gouspillou, G. Parkin Overexpression Attenuates Aging-related Muscle Atrophy in Mice. FASEB J. 2017, 31, 713.11.

119. Rodriguez-Navarro, J.A.; Casarejos, M.J.; Menendez, J.; Solano, R.M.; Rodal, I.; Gomez, A.; Yebenes, J.G.; Mena, M.A. Mortality, oxidative stress and tau accumulation during ageing in parkin null mice. J. Neurochem. 2007, 103, 98-114. [CrossRef] [PubMed]

120. Shimada, K.; Crother, T.R.; Karlin, J.; Dagvadorj, J.; Chiba, N.; Chen, S.; Ramanujan, V.K.; Wolf, A.J.; Vergnes, L.; Ojcius, D.M.; et al. Oxidized mitochondrial DNA activates the NLRP3 inflammasome during apoptosis. Immunity 2012, 36, 401-414. [CrossRef] [PubMed]

121. Oka, T.; Hikoso, S.; Yamaguchi, O.; Taneike, M.; Takeda, T.; Tamai, T.; Oyabu, J.; Murakawa, T.; Nakayama, H.; Nishida, K.; et al. Mitochondrial DNA that escapes from autophagy causes inflammation and heart failure. Nature 2012, 485, 251-255. [CrossRef] [PubMed]

122. White, M.J.; McArthur, K.; Metcalf, D.; Lane, R.M.; Cambier, J.C.; Herold, M.J.; van Delft, M.F.; Bedoui, S.; Lessene, G.; Ritchie, M.E.; et al. Apoptotic caspases suppress mtDNA-induced STING-mediated type I IFN production. Cell 2014, 159, 1549-1562. [CrossRef] [PubMed] 
123. Franceschi, C.; Bonafe, M.; Valensin, S.; Olivieri, F.; De Luca, M.; Ottaviani, E.; De Benedictis, G. Inflamm-aging. An evolutionary perspective on immunosenescence. Ann. N. Y. Acad. Sci. 2000, 908, 244-254. [CrossRef] [PubMed]

124. Youm, Y.H.; Grant, R.W.; McCabe, L.R.; Albarado, D.C.; Nguyen, K.Y.; Ravussin, A.; Pistell, P.; Newman, S.; Carter, R.; Laque, A.; et al. Canonical Nlrp3 inflammasome links systemic low-grade inflammation to functional decline in aging. Cell Metab. 2013, 18, 519-532. [CrossRef] [PubMed]

125. Jacobs, J.L.; Coyne, C.B. Mechanisms of MAVS regulation at the mitochondrial membrane. J. Mol. Biol. 2013, 425, 5009-5019. [CrossRef] [PubMed]

126. Lopez-Armada, M.J.; Riveiro-Naveira, R.R.; Vaamonde-Garcia, C.; Valcarcel-Ares, M.N. Mitochondrial dysfunction and the inflammatory response. Mitochondrion 2013, 13, 106-118. [CrossRef] [PubMed]

127. Voloboueva, L.A.; Lee, S.W.; Emery, J.F.; Palmer, T.D.; Giffard, R.G. Mitochondrial protection attenuates inflammation-induced impairment of neurogenesis in vitro and in vivo. J. Neurosci. 2010, 30, 12242-12251. [CrossRef] [PubMed]

128. Christensen, K.; Doblhammer, G.; Rau, R.; Vaupel, J.W. Ageing populations: The challenges ahead. Lancet 2009, 374, 1196-1208. [CrossRef]

129. Mc Auley, M.T.; Guimera, A.M.; Hodgson, D.; McDonald, N.; Mooney, K.M.; Morgan, A.E.; Proctor, C.J. Modelling the molecular mechanisms of aging. Biosci. Rep. 2017, 37. [CrossRef] [PubMed]

130. Longo, V.D.; Mattson, M.P. Fasting: Molecular mechanisms and clinical applications. Cell Metab. 2014, 19, 181-192. [CrossRef] [PubMed]

131. Longo, V.D.; Panda, S. Fasting, Circadian Rhythms, and Time-Restricted Feeding in Healthy Lifespan. Cell Metab. 2016, 23, 1048-1059. [CrossRef] [PubMed]

132. Finkel, T. The metabolic regulation of aging. Nat. Med. 2015, 21, 1416-1423. [CrossRef] [PubMed]

133. McPhee, J.S.; French, D.P.; Jackson, D.; Nazroo, J.; Pendleton, N.; Degens, H. Physical activity in older age: Perspectives for healthy ageing and frailty. Biogerontology 2016, 17, 567-580. [CrossRef] [PubMed]

(C) 2018 by the authors. Licensee MDPI, Basel, Switzerland. This article is an open access article distributed under the terms and conditions of the Creative Commons Attribution (CC BY) license (http:/ / creativecommons.org/licenses/by/4.0/). 